\title{
ЭСТЕТИКА БАРОККО В ТВОРЧЕСТВЕ Л. ДЕ ГОНГОРЫ И Э. ШКЛЯРСКОГО
}

Любецька В. В. Естетика бароко у творчості Л. де Гонгори та Е. Шклярського.

У статті розглядається феномен бароко, особливості художнього стилю $\mathrm{i}$ барокове світовідчуття. Досліджуються різні стильові тенденції, контрастність іспанського бароко, у якому розвиваються i стикаються дві течії: культизм (культеранізм) і консептизм. Осмислюється «темний стиль» Л. де Гонгори, який еволюціонує у творчості поета і має своє продовження в літературі і культурі XXI ст. Аналізується трагічне протистояння світу i людини, приховане у поезії Е. Шклярського, прихильника «темного стилю».

Ключові слова: бароко, культизм, консептизм, «темний стиль», трагічне.

Любецкая В. В. Эстетика барокко в творчестве Л. де Гонгоры и Э. Шклярского.

В статье рассматривается феномен барокко, особенности художественного стиля и барочное мироощущение. Исследуются различные стилевые тенденции, контрастность испанского барокко, в котором развиваются и сталкиваются два течения: культизм (культеранизм) и консептизм. Осмысливается «темный стиль» Л. де Гонгоры, эволюционирующий в творчестве поэта и имеющий свое продолжение в литературе и культуре XXI ст. Анализируется трагическое противостояние мира и человека, сокрытое в поэзии Э. Шклярского, приверженца «темного стиля».

Ключевые слова: барокко, культизм, консептизм, «темный стиль», трагическое. 
Lubetskaya V. V. Baroque aesthetics in the works of L. de Gongora and E. Szklyarskiy.

The article discusses the phenomenon of Baroque, the features of art style and baroque world-view. It is researched the various stylistic tendencies, the contrast of Spanish Baroque, in which two trends develop and face each other: cultism (culteranizm) and conceptism. The «dark style» of L. de Gongora, which evolves in the poet's creativity and has its extension in literature and culture of the XXI century, is interpreted. It is analyzed the tragic confrontation of the world and human-being, hidden in the poetry of E. Shklyarskiy who was adherent of the «dark style».

Key words: baroque, cultism, conceptism, «dark style», tragic.

Барокко (итал. barocco - «странный», «причудливый») литературный стиль, господствующий в Европе с кон. XVI, XVII и нач. XVIII ст. Существуют различные представления об эстетической природе феномена барокко: его понимают и как «декаданс в искусстве эпохи Возрождения» (Я. Бурхард), и как «новую фазу искусства Ренессанса» (Г. Вельфлин) [8, с. 101]. Исследуя барочный стиль, Т. В. Михальченко в своей статье «К вопросу об этапах изучения художественного стиля барокко» отмечает, что Г. Вельфлин производит переворот в искусствоведении, «реабилитируя» эпоху барокко. Швейцарский историк искусств говорит не об убожестве барочных форм, a о «впечатляющей игре видимостей, находя в экстравагантных контурах модель создания неосязаемой иллюзии, колеблющейся между небом и землей» [8, с. 101]. Именно новое мироощущение определяет возникновение стиля барокко, который порождает новые жанры и формы искусства.

Барочный мир многосложен и противоречив, и в барочной литературе осуществляется попытка описать мир в его многообразии, осмыслить трагическое противостояние мира и человека, следовательно, видение бытия и отдельной человеческой личности пессимистично. Не отрицая величия Бога, культура барокко сомневается в прочности и непоколебимости сотворенного Им мира. Человек не ренессансный титан мысли, способный ответить на божественное творение своим творчеством, а «ничтожная песчинка», которая может погрязнуть в собственных сомнениях и страхах, став, таким образом, на путь зла.

Огромный, изменчивый, расколотый мир поглощает человека, что определяет фатальность его судьбы. Отсюда и фантастические элементы, включенные в художественный мир барочных писателей, преувеличенная аффектированность, превалирование чувств, накал тревожных страстей, соединение явлений полярных - добра и зла, 
возвышенного и низменного, трагического и комического. «Бьющий ключом оптимизм людей Ренессанса, выдвинутый ими идеал гармонически развитой личности часто сменяется у поэтов барокко мрачной оценкой действительности, а восторженное преклонение перед человеком и его возможностями - подчеркиванием его двойственности, непоследовательности, испорченности; обнажением вопиющего несоответствия между видимостью вещей и их сущностью изображением разорванности бытия, столкновения между началом телесным и духовным, между привязанностью к чувственной красоте мира и осознанием бренности земного существования» [4].

Смиряясь и принимая такой несовершенный миропорядок, представители барокко предполагают, что все сущее имеет некий сокрытый смысл. Соприкасаясь с тайной мира, культура и литература барокко приходит к пониманию Бога как «высшей разумности», обладающей огромной созидающей мощью и милосердием, тогда человеческое существо, сочетающие в своей природе добро и зло, может надеяться на исправление порока и возможность чуда при постижении божественного предначертания. Так на фоне трагического начала возникают и религиозные мотивы, тема смерти и тема загробной жизни, где должны прекратиться страдания грешного человека. Чувственный мир воспринимается как нечто «одухотворенное божественным началом», с одной стороны, а с другой - «номиналистическое и импрессионистическое воспроизведение» этого мира [3].

Барочное миропредставление порождает и характер изображения мира в художественных произведениях: необычность, экспрессивность художественных средств, асимметрия, динамика, «стремление ввысь», живописность и красочность, предельная эмоциональная напряженность и внимание к душевному миру человека, экзальтация чувств, выразительный показ глубочайших и потаенных страданий. Ю. Б. Виппер указывает на тяготение барочного стиля к патетике, особенно в его аристократических вариантах, где это принимает «нередко характер напыщенности и аффектации, за которыми скрывается, по существу, отсутствие подлинного чувства, суховатый и умозрительный расчет» [4].

Вместе с тем аналогичные тематические, образные и стилистические мотивы обретают у отдельных представителей литературы барокко несходное, а временами и прямо противоположное 
идейное звучание. Барокко не знает покоя и статики, оно нелинейно, мир предстает меняющимся и подвижным, чрезмерность приводит к безудержному полету фантазии, к усложнению образов и языка (символичность, метафоричность, декоративность, театральность, гиперболичность, аллегоричность, ироничность, гротеск). Сталкивая самые различные чувства (подлинное и мнимое, желаемое и действительное, кажущееся и реальное), культура и искусство барокко значительно потеснили разум.

Литература барокко представлена различными стилевыми тенденциями. Две основные линии - аристократическое, элитарное барокко и демократическое, «низовое». Сразу отметим, что типологические черты барокко определили и подвижность жанровой системы. Ведущими жанрами становятся трагикомедия, роман с его жанровыми разновидностями (героический, комический, философский), пастораль, бурлеск, пародирующий высокие жанры. Во всех жанрах выстраивается «мозаичная» картина мира, где воображение художника играет огромную роль.

Поэзия испанского барокко весьма контрастна, но изнутри этой контрастности прорастает общее ощущение, объединяющее художественные миры различных поэтов - хаотичности окружающего бытия, жизненной неполноты, расколотости земного существования. По мнению Ю. Б. Виппера: «Постижение барокко как единства больше всего затрудняет то обстоятельство, что оно представляет собой единство, которое состоит из сплошных противоречий» [3]. Стоит сказать, что развитие поэзии в Испании XVII столетия предопределяет ее контрастность, в испанском барокко развиваются и сталкиваются два различных течения: культизм (культеранизм) и консептизм. Основоположником и крупнейшим представителем культизма в испанской барочной поэзии был Луис де Гонгора, по имени которого было названо и направление - «гонгоризм».

Творчество Франсиско де Кеведо - вершина консептизма, представляет вторую творческую манеру, которая отличается парадоксальностью и раскрывает глубинные и неожиданные связи за счет сопоставления и сопряжения различных объектов через слово и мысль. Комическое начало, бурлеск, остроумие и сатирическое осмеяние у Ф. де Кеведо сочетается с пессимистическим взглядом на современную ему действительность. Таким образом, консептизм сосредоточен не только на простой игре слов, через нее и благодаря ей 
он проникает и вскрывает противоречия общественного бытия, заключая в себе реалистическую потенцию. Консептизм - это «трудный стиль» (по Р. М. Пидалю), где огромное значение имеют многозначность и каламбур. Писатели консептисты формулирует мысли, идеи, концепты максимально выразительно, лаконично, усложняя язык произведений за счет смысловой насыщенностью каждого слова и фразы.

В культизме прекрасное и возвышенное искусство - «башня из слоновой кости», оно может быть доступно только немногим избранным, служит, по мнению Л. де Гонгоры, интеллектуальной элите. Гармония искусства противопоставлена безобразному действительности.

Исследователи говорят о двух стилях в творчестве Л. де Гонгоры «ясный стиль» представляет первый период его творчества, условно это произведения (оды, сонеты, романсы), изданные до 1610 г. «Ясный стиль» отличается тематической широтой и понятностью слога, он частично связан с фольклорной традицией.

И второй, «темный стиль», изобилующий загадочными метафорами, латинизмами, неологизмами, перифразами, инверсиями, характерен для произведений последних лет жизни поэта. «Темный стиль» у Л. де Гонгоры эволюционирует и в больших поэмах «Предание о Полифеме и Галатее» (1613), в «Уединении» (1612-1613) черты данного стиля выявляются отчетливо. Это свидетельство формирования новой стилистической системы культизма, которую создал Л. де Гонгоры.

Мир, творимый Л. де Гонгорой, ночной, волшебный и хрупкий, поэт осознает как его иллюзорность, так и невозможность абсолютного ухода от дневной яви. И все таки, истинная красота, немыслимая в окружающей, трагически понятой Л. де Гонгорой, реальности, обретает свое идеальное существование в художественном произведении.

Для консептистов стиль Л. де Гонгоры и его последователей «гонгористов» был верхом искусственности, это и не удивительно, потому что демократическая поэзия более направлена на «изящный ум», на остроумие, а не на раскрытие тайного смысла. Криптография Л. де Гонгоры, понимание его причудливых и странных образов могло быть доступно немногим ценителям поэзии. 
«Темный стиль», «ученая поэзия» в философии и эстетике культизма имеет неоценимые преимущества перед прозаической ясностью, криптографический стиль обладает витиеватой формой и исключает бездумное чтение, постижение содержания, проникновение к смыслу - сложный процесс вдумчивого и медленного чтения. Преодоление подобных трудностей зашифрованной поэзии доставляет наслаждение внимательному читателю.

Темы стихов Л. де Гонгоры почти всегда просты, но их воплощение замысловато. «Темный стиль» Л. де Гонгоры живописный, он обращен к зрению и слуху, но главным образом - к интеллекту читателя. Большинство произведений Л. де Гонгоры посвящены типично барочной теме бренности жизни, хрупкости красоты. Таков главный мотив знаменитого сонета «Пока руно волос твоих течет...», восходящий к Горацию, который доводит до сознания читателя бренность человеческой жизни. К этим размышлениям обращались многие поэты, в том числе и трагический Т. Тассо. Но наиболее безысходно звучит мотив краткости, мгновенности жизни, мимолетности красоты и молодости в сонете Л. де Гонгоры.

Одним из главных приемов в барочной эстетике является контраст. На контрасте построено и поэтическое произведение Л.де Гонгоры: юность и старость, красота и уродство, но главное противопоставление жизнь и смерть. Красоте и молодости не просто суждено поблекнуть и увянуть, ей суждено превратится в «пепел» и в «прах»:

Пока руно волос твоих течет,

Как золото в лучистой филиграни,

И не светлей хрусталь в изломе грани,

Чем нежной шеи лебединый взлет,

Пока соиветье губ твоих ияветет

Благоуханнее гвоздики ранней

И тшщетно снежной лилии старанье

Затмить чела чистейший снег и лед,

Спеши изведать наслажденье в силе,

Сокрытой в коже, в локоне, в устах,

Пока букет твоих гвоздик и лилий

Не только сам бесславно не зачах,

Но годы и тебя не обратили

В золу и в землю, в пепел, дым и прах (Пер. С. Гончаренко). 
Л. де Гонгора говорит о диссонансе мира, о скрытой, и оттого пугающей, быстротечности жизни. Трудным оказывается определение и изучение диалектической связи формы и содержания в произведении Л. де Гонгоры. Подчеркнем стройность и гармоничность композиции данного стихотворения. Быстротечность времени выражается в повторении слова «пока»: «Пока руно волос твоих течет», «Пока соцветье губ твоих цветет», «Пока букет твоих гвоздик и лилий... не зачах».

Перед нами вычурный женский образ, поэт заостряет особенность и изысканность красоты: волосы - «золото в лучистой филиграни», чело - «чистейший снег и лед», губы - благоуханные гвоздики, шея - сияющий хрусталь. Но все прелестями юной девы приобретают чуть холодноватый оттенок, их описание носит рассудочный характер. И далее происходит эмоциональный взрыв - в конечном счете, красота обратится «в золу и в землю, в пепел, дым и прах». Пессимистическая идея произведения получает в финальных строках наибольшее раскрытие. Исступленность, которая овладевает поэтом, позволяет ему изрекать истины и пророчествовать, сказывая подлинный смысл несокрыто.

Барочные традиции нашли дальнейшее развитие в европейских литературах XIX-XX ст. В XX ст. появилось и литературное течение необарокко, которое связывают с авангардной литературой начала $\mathrm{XX}$ ст. и литературой постмодернизма конца XX ст.

Русское барокко - явление неоднозначное и трудноуловимое. Как литературное направление русское барокко формируется под влиянием нескольких культур: украинской, белорусской и польской. Выражается это в появлении новых интересов, воззрений, а главное в идеях, темах, жанрах, в возникновении необычного стиля.

Отдельные барочные черты стали проявляться в литературе XXI ст.

Так, незнакомый, параллельный мир открывает группа «Пикник» в своем творчестве, работающая в жанре прогрессивного рока, арт-рока и нью-вэйв. Особого внимания литературоведов заслуживают альбомы «Королевство кривых» (2005), «Мракобесие и джаз» (2007), «Театр абсурда» (2010), где элементы барочного стиля выступают наиболее ярко. Рассматривая художественные тексты, мы, вслед за Платоном, подразумеваем, что слово первично по отношению к ритму и напеву $[11$, с. 166]. Е. В. Герцман пишет, что «существует много доказательств 
того, что в определение «поэт» вкладывалось и понятие «музыкант» [5, с. 124]. Именно в «стихии языка» Вяч. Иванов усматривает порождающее лоно поэзии [6, с. 141].

Итак, лидер группы Э. Шклярский (поэт и музыкант) приверженец «темного стиля»; его желание заложить некоторую парадоксальность в слова и как можно короче изложить свою мысль уходит корнями в эстетику барокко, конкретнее - в «гонгоризм». Личное ощущение тревоги и радости больше характеризует реальность, по мысли Э. Шклярского, чем слово, но руководствуется Э. Шклярский словами, поскольку они и создают состояния.

В поэзии Э. Шклярского нет конкретики, мир разомкнут и открыт, его создание и ощущения, вызываемые созданным миром - основная задача поэта. Погружая человека в особое пространство, Э. Шклярский рассчитывает на то, что это пространство будет раскрыто, расшифровано слушателем, так как «даже в самом пустом из самых пустых есть двойное дно» («Инквизитор», альбом 1998 г. «The Best»).

Как правило, все песни «Пикника» «существуют в состоянии первичного зачатия» (по Э. Шклярскому), то есть одна фраза способна составить внутреннюю жизнь произведения. Закодированные образы глубоко метафоричны, многосмысленны, потому их восприятие у различных слушателей может быть отлично, так как тексты и музыка группы «Пикник» символичны, и написаны в «нескольких слоях».

Обратимся к тексту песни «Смутные дни» из альбома «Женьшень» (1996), который можно воспринимать как литературное произведение благодаря своей поэтичности и законченной композиции. Отметим необычность в названии альбома - «Женьшень», хотя правильное написание - «женьшень», известное лекарственное растение восточной медицины. Раздельное написание этого слова - аллегория дискомфорта и стремление к недостижимой цельности.

Единственное упоминание слова «жень-шень» мы встречаем именно в песни «Смутные дни»: «так закипай же в крови, женьшеневый сок...». Весьма характерная для «Пикника» особенность - называть альбом словом, которое упоминается именно один раз и вскользь, но имеет ключевое значение для понимания смысла целого (альбом «Харакири» 1991 г. песня «Настоящие дни»; альбом «Стекло» 1997 г. песня «С высоты некуда упасть»). Другая особенность наименования - название альбома совпадает с названием 
одной из песен, смысл которой - лейтмотив, объединяющий все произведения (альбомы «Пить электричество» (1999), «Египтянин» (2001), «Говорит и показывает» (2003).

Мотивы «закипания» и «расплавления» в альбоме «Жень-шень» вспомогательные, продолжающие тему дискомфорта. Жень-шень не лечит, а «кипит в крови» (физическое ощущение боли и безысходность пропадающей души):

Какие смутные дни, как дышит ветер тревог.

И мы таниуем одни, на пыльной ленте дорог.

Как будто клятва дана - ничем не дорожить.

А только в этих волнах кружить.

Так закипай же в крови женьшеневый сок.

Пропадай душа, беги земля из под ног.

Так лети голова вместе с листьями вниз.

Такие смутные дни. Такие смутные дни.

Изакипает в крови женьшеневый сок.

И чей-то пристальный взгляд нацелен прямо в висок.

Так лети голова вместе с листьями вниз.

Такие смутные дни. Смутные дни (Э. Шклярский).

Художественным открытием автора данного произведения является исповедальность и предельная искренность. События духовной жизни интересуют поэта больше, чем внешние обстоятельства, «смутные дни». Поэта волнует сам процесс внутреннего движения.

Трагически соединяются любовь к жизни и стремления к смерти, ощущение обреченности и дисгармоничности - «Какие смутные дни, как дышит ветер тревог». Тревожные предчувствия терзают героя, он фактически прощается с бренным миром, желая выпорхнуть из него. Мир беспорядочен и человек - всего лишь жалкая и безвольная игрушка в руках недоступных сил, его одиночество и марионеточность подчеркивается в строках: «И мы танцуем одни, на пыльной ленте дорог. Как будто клятва дана - ничем не дорожить. А только в этих волнах кружить».

Человеческая жизнь - цепь случайностей и уже в силу этого представляет собой хаос. И раз мир пребывает в состоянии неустойчивости, ему присуще имманентное состояние перемен, а 
закономерности его трудноуловимы, если вообще постижимы, то человек обречен и жизнь его - мгновение: «Пропадай душа, беги земля из под ног. Так лети голова вместе с листьями вниз. Такие смутные дни. Такие смутные дни». Закипающий женьшеневый сок в крови героя сочетается со страхом, с опасностью, грозящей отовсюду (то «летящая голова», как будто отрубленная на плахе, то не прозвучавший выстрел «взгляд, нацеленный в висок»: «И закипает в крови женьшеневый сок. И чей-то пристальный взгляд нацелен прямо в висок»). И рефреном повторяются строки: «Так лети голова вместе с листьями вниз. Такие смутные дни. Смутные дни».

«Смутные дни» - это голос рока, различаемый среди иных голосов и ветра, это смутное ожидание предстоящей гибели «целого мира» и явное ощущение усиливающегося, надвигающегося первозданного хаоса, захватывающего человеческое существо.

Таким образом, можно сделать вывод о мистичности барочного мировидения и самого мира, который постижим через сокровенную суть вещей. Художественная система барокко сложилась в XVII в., но с отдельными элементами данного стиля мы встречается и в нынешнее время во многих жанрах и у различных авторов. Отдельного внимания заслуживает вопрос о национальном своеобразии барокко в европейских литературах. Диалогическая природа барокко расценивается, как постоянная способность актуализировать всевозможные смыслы и формировать новые образы в сознании человека. Эпоха барокко определила динамику формирования культур последующих эпох, явив собою зрелую культуры, выработав оригинальный художественный стиль с его живописностью и метафорической усложненностью. Представляя мир как театр (барочные попытки истолкования темы «жизнь есть театр» сходятся в признании «тщеты жизни» [1, с. 103]), в котором человек - марионетка в руках демиурга, как лабиринт, барокко трагично и одновременно возвышенно по своей сути.

\section{Литература}

1. Barner W. Barockrhetorik. Barockrhetorik. Untersuchungen zu ihren geschichtlichen Grundlagen. Tübingen / W. Barner. - M. : Niemeyer, 1970.

2. Вельфлин Г. Ренессанс и барокко / Г. Вельфлин. - СПб. : Азбука-классика, 2004. $-288 \mathrm{c}$.

3. Виппер Ю. Б. О разновидностях стиля барокко в западноевропейских литературах XVII века [Электронный ресурс] / Ю. Б. Виппер. - Режим доступа : http://17v-euro-lit.niv.ru/17v-euro-lit/articles/vipper-o-stilyah-barokko.htm. 
4. Виппер Ю. Б. Поэзия барокко и классицизма [Электронный ресурс] / Ю. Б. Виппер. - Режим доступа : http://www.philology.ru/literature3/vipper-90d.htm.

5. Герцман Е. В. Музыка Древней Греции и Рима / Е. В. Герцман. - СПб. : Алетейя, 1995.

6. Иванов В. И. Родное и вселенское / В. И. Иванов. - М. : Республика, 1994.

7. Испанская эстетика. Ренессанс. Барокко. Просвещение / вст. ст. А. Л. Штейна; пер. с испан. - М. : Искусство, 1977. - 696 с.

8. Михальченко Т. В. К вопросу об этапах изучения художественного стиля барокко / Т. В. Михальченко // Філологічні студії : Науковий вісник Криворізького державного педагогічного університету : зб. наук. праць. - Кривий Ріг, 2008. - Вип. 1. - С. 97-105.

9. Морозов А. А. Проблемы европейского барокко / А. А. Морозов // Зарубежная литература. - Л., 1968. - №12. - С. 111-126.

10. Пинский Л. Е. Ренессанс. Барокко. Просвещение / Л. Е. Пинский. - М. : РГГУ, 2002. $-832 \mathrm{c}$.

11. Платон Собр. починений : в 4 т. / общ. ред. А. Ф. Лосева, В. Ф. Асмуса, А. А.Тахо-Годи. - М. : Мысль, 1994. - Т.3. - 1994. - 654 с.

Стаття надійшла до редакції 06.09.2012 р. 